\title{
Norwegian Teacher Educators' Attentiveness to Democracy and their Practices
}

\author{
Heidi Biseth \\ University of South-Eastern Norway \\ Susan Catherine Lyden \\ University of South-Eastern Norway
}

\begin{abstract}
The aim of the study is to gain insight into teacher educators' attentiveness to democracy, i.e. how they understand democracy and how they describe their own practices of instilling democratic competencies and values in pre-service teachers. Through using a questionnaire modified from the Global Doing Democracy Research Project, we elicited responses from 153 respondents. The material was analysed using "thin" versus "thick" notions of democracy and three categories of citizenship. The results of this study indicate that teacher educators primarily understand democracy as a societal structure, a way of politically organizing a society in which elections are a core activity. Hence, their practice reflects this somewhat thin understanding of democracy. Overwhelmingly, they perceive the two dominant ways of promoting democracy to be to encourage students to take part in formal participatory structures and to engage students in discussions and debates within the classroom.
\end{abstract}

Keywords: democracy and education; citizenship education; democratic competencies; democracy in teacher education.

\section{Introduction}

Based on the results from the IEA International Civic and Citizenship Education Study (ICCS) 2009 (Fjeldstad et al., 2010) Norwegian teenagers display a relatively high knowledge and understanding of democracy compared to their peers in other countries. The ICCS study was repeated in 2016 and results indicate an even sounder knowledge base and understanding of democracy among the Norwegian student population (Huang et al., 2017). The performance of Norwegian students in both ICCS 2009 and 2016 is considered, among other things, a testament to the Norwegian school system and its teachers. In order to deduce that Norwegian teacher educators also contribute here, we need to establish to what degree they provide a teacher education endorsing democratic knowledge, attitudes and skills among teachers-to-be. 
The aim of our study is to investigate how teacher educators in Norway perceive, experience, and understand democracy, and if their notions of democracy actually shape their practices in teacher education for and through democracy. The mandate provided to the education sector includes ensuring that students have the knowledge, attitudes and skills necessary to be active democratic citizens (Biseth, 2009; Kunnskapsdepartementet, 2016). Teacher educators and teacher education programs in Norway are expected to foster new teachers capable of instilling democratic citizenship, values and virtues in their future students. The Regulations Relating to the Framework Plan for Primary and Lower Secondary Teacher Education for Years 1-7 and Years 5-10 state that the teacher education programs shall qualify pre-service teachers "...to help reinforce the role of schools as institutions of formative development and learning in a democratic and diverse society" (Ministry of Education and Research, 2016a, p. 1; 2016b, p. 1). Revisions to the National Curriculum for Primary and Secondary Education make it clear that democracy and citizenship are intended to cut across all topics in school (Kunnskapsdepartementet, 2016). How teacher educators interpret learning outcomes on democracy and democratic participation in their own teaching and learning activities will influence the pre-service teachers' competencies in conveying the required knowledge, attitudes and skills to their future students. Most work on democracy and education in Norway is conducted in or about schools (e.g., Biseth, 2012; Haugen et al., 2014; Huang et al., 2017; Mikkelsen et al., 2011; Solhaug, 2003; Stray \& Sætra, 2015), not on teacher education or teacher educators. Two recent studies, however, engage with pre-service teachers. Wistrøm \& Madsen (2018) have conducted a study including 18 pre-service teachers in the natural science subject. They conclude that the students have a limited understanding of democracy, and the link between democracy and teaching the subject. Eriksen (2018) studied how pre-service teachers understand the theoretical concepts of democracy and in what ways they intended to operationalize it with future pupils. The pre-service teachers, however, do not to a great extent seem to understand democracy as a pedagogical term, but rather as a purely political notion.

The aim of our study being to gain insight into which understandings of democracy teacher educators are concerned to instil in pre-service teachers. We have asked the following questions:

Is there an understanding of democracy where critical thinking and participation are seen as fundamental requirements to ensure human rights, sustainability and social justice? Alternatively, do teacher educators think that ensuring preservice teachers have knowledge of structural aspects of democracy, such as elections, representation, voting, and participation, is sufficient to fulfil their mandate as teachers?

This article is based on research conducted within the framework of the largescale comparative project: the Global Doing Democracy Research Project (GDDRP) (Carr et al., 2014). The Norwegian project includes teacher educators and pre-service teachers at national level. In this article, we will analyse teacher educators' perceptions and understanding of democracy and their self-reported 
activities with their pre-service teachers that they themselves see as core in their democratic education. In the Global Doing Democracy Research Project, the questions move beyond quantitative modes of inquiry, including open-ended questions eliciting an in-depth and critical understanding on how teachers and, in this case, teacher educators construct democratic literacy, engagement and transformation. It is as such complementary to large-scale quantitative studies such as the IEA ICCS study (Schulz et al., 2010).

\section{A brief country contextualisation}

Norway is located in the Northern part of Europe, considered one of the Scandinavian countries and with a relatively low population and high standards of living and a high life expectancy rate.

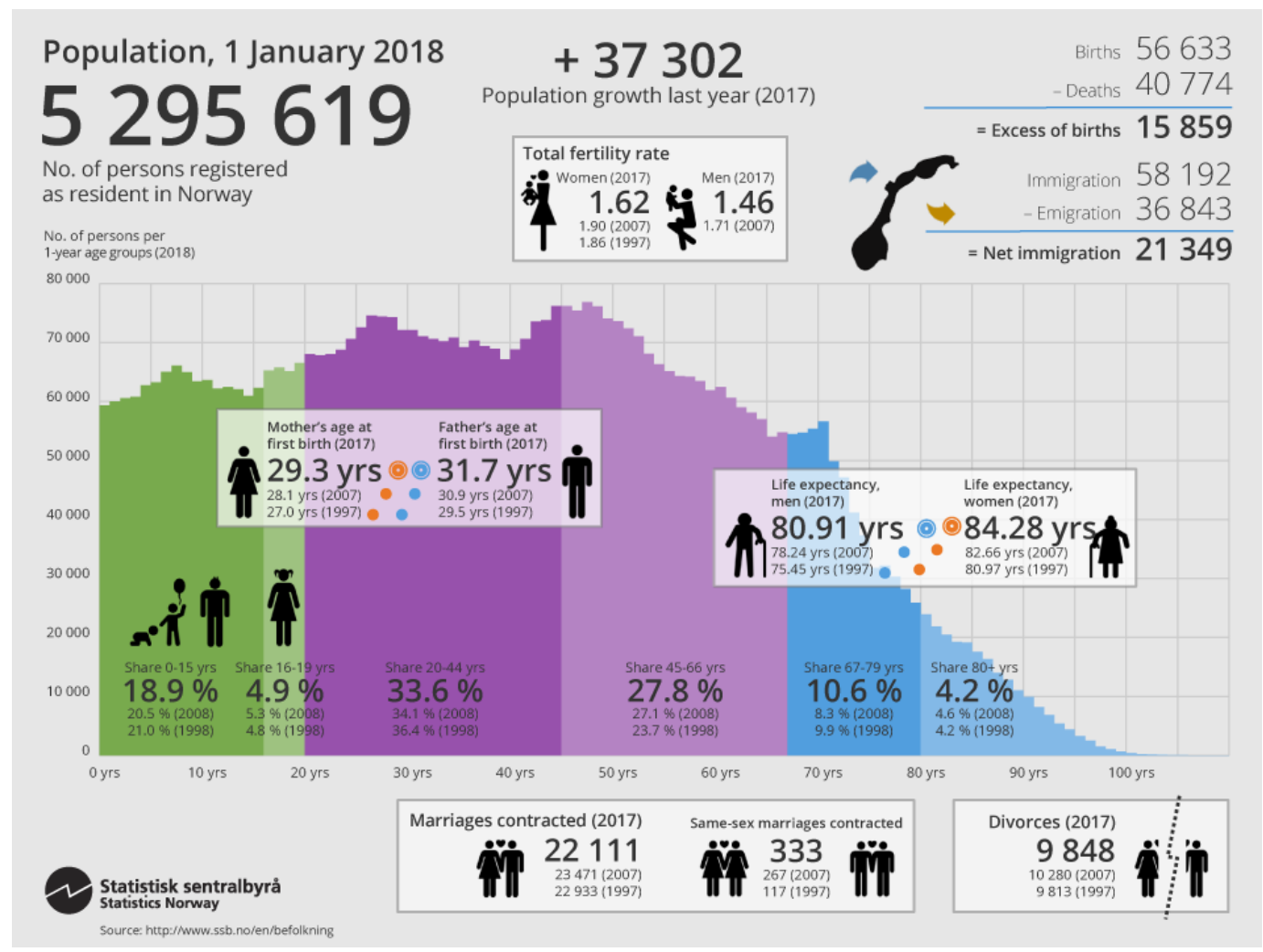

Figure 1 - Key figure of the Norwegian population Source: Statistics Norway (2018)

Norway is considered a country with a stable democratic tradition (cf. Selle \& Østerud, 2006). The 1814 Constitution is one of the oldest in the world and is celebrated on the National Day, May 17, every year. The country's long history of democracy, social welfare system and social stability, based on fundamental democratic values, such as human rights, are some of the factors leading to the top score in The Economist Intelligence Unit's Democracy Index (2018) since 2010. The democratic history and the way it is supposed to permeate the country and the education sector are elements we expect to be reflected in the teacher education system and among teacher educators. 


\section{Attentiveness to democracy}

The teacher educators in this study are from a range of subject areas and all show to some degree an understanding of the inextricable link between democracy and education. In this article, we use the conceptual framework of thin and thick democracy (Barber, 1984/2003; Gandin \& Apple, 2002), as well as the taxonomy of what is perceived as constituting a good citizen by Westheimer and Kahne (2004). We believe that this shows differences in how the respondents perceive democracy and what practices this generates for their work with students. The aim of how a teacher conduct democratic citizenship is, at least implicitly, to invoke democracy (cf. Levinson, 2011). In addition, we concur with Parker (1996) that a sustainable democracy necessitates citizenship education since democratic traits and civic competencies are not naturally occurring in humans.

Democracy can be described as both thick and thin (Barber, 1984/2003; Gandin \& Apple, 2002). A respondent who puts most emphasis on elections, and the institutions of liberal democracy, ensuring teachers have the skills and knowledge to teach about democracy, would be said to have a thin understanding of democracy. Reducing democracy to elections and institutions minimizes the role of the citizen and of education for social justice, separating democratic processes from the social processes that affect communities and everyday life. One of the aims of education is to contribute to the development of young citizens who perceive social justice as critical in a sustainable democracy and, subsequently, this needs to influence the ways in which we perceive the role of teacher educators and ways in which they need to be attentive to democracy in order to address their mandate.

Thick democracy, on the other hand, goes beyond the championing of electoral and legislative processes, rule of law and basic civil rights, and would seek to instil in students the legitimacy of collective citizenship and civil action. Thick democracy envisages a 'social citizen', an individual always in relationship with others and capable of reflexive agency (Zyngier, 2012, p. 5). This demands that teacher educators can instil in their students a deeper understanding of what it means to teach for and through democracy towards social justice and a more sustainable society. We concur with Barber's critical perspectives that for a democratic society to be sustainable and prosper, to adequately respond "to the dilemmas of modern politics", a strong democracy is needed (Barber, 1984/2003, p. 120). An understanding of "thick" or "strong" democracy we see as closely linked to the intended role of education in promoting democracy. The role of social justice is seen here as intrinsic to democracy. As such, the description of thin versus thick democracy describes two ends of a continuum, in our opinion (see also Levinson, 2011). A teacher educator's perception of democracy along this continuum will influence the citizenry she promotes through her own teaching. Westheimer and Kahne's (2004) three categories of citizen provides an additional layer to the continuum of thin and thick democracy. In their model, they describe the kind of behaviour a citizen would be expected to display to be judged as a "good" citizen within different understandings of democracy (Westheimer \& Kahne, 2004, p. 237). Described as, the personally responsible citizen, the participatory citizen and the justice oriented citizen (Westheimer \& 
Kahne, 2004, p. 240), each category, in addition to reflecting a particular understanding of democracy and citizenship, also reflects a distinct set of curriculum choices and classroom practices. These categories should not be seen as separate or exclusive, but expanding from one to another through additional behaviours and expectations. Parker (1996) discussed a similar model almost a decade earlier in which he focused on the educational practices based on the understanding of democracy and a good citizen. He used the terms 'traditional', 'progressive', and 'advanced' conceptions of citizenship education. Parker's model is interesting and useful, but is developed in particular to judge citizenship education in a multicultural society. We are engaged with education in general and, hence, continue to use Westheimer \& Kahne's model. In Figure 2 below, we illustrate how we see the notions of thick and thin democracy by Barber related to the three categories of citizens by Westheimer and Kahne.

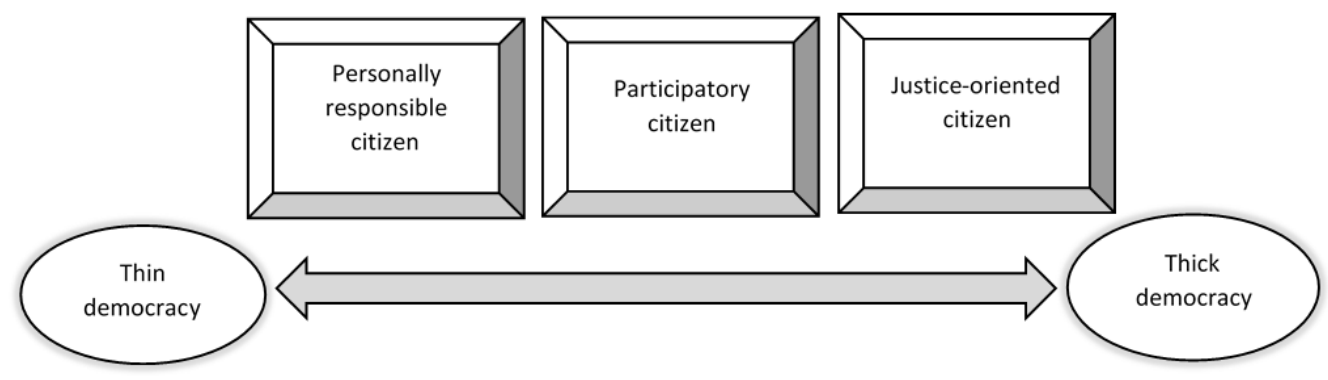

Figure 2 - Merging perceptions of democracy with categories of citizens

Source: Developed based on Barber (1984/2003) and Westheimer and Kahne (2004)

Teacher educators who work towards promoting character-building and responsible citizens - e.g. paying taxes, recycling, engaging in helping others in time of crisis, obeying laws and fulfilling a sense of duty in society, can be seen as promoting the ideas of the personally responsible citizen (Westheimer \& Kahne, 2004).

If the teacher educator is preoccupied with providing knowledge about, how the democratic system works, strategies to engage in political decision-making and local community efforts to promote change, it could be argued that the teacher educator promotes the idea of a participatory citizen. Knowing, for example, how to organize food distribution locally, advocate a fairer tax system or support a Food waste Bill such as that introduced in France ${ }^{1}$ forcing supermarkets to give food away rather than throw it out. Education for participatory citizenship will generally entail a focus on knowledge about democratic systems, and the same time, a connection between experiences in the classroom and the lived experiences outside of the classroom. In teacher education, this could be visible when pre-service teachers are encouraged to engage in the existing structures of

\footnotetext{
${ }^{1}$ See The Guardian December 12, 2015. Can be retrieved from https://www. theguardian.com/world/2015/dec/10/france-vote-force-supermarkets-give-awayunsold-food-waste
} 
local democracy such as the students' council or other bodies relevant to meeting the needs and wishes of the student population.

The third category by Westheimer and Kahne (2004) is identified as the justiceoriented citizen, and the category closest to Barbers' understanding of strong democracy (Barber, 1984/2003). Participation is here supplemented with critical enquiry and the willingness to address areas of injustice and stimulate systemic change. In our example acting to find the sources of poverty and inequality and "to act to solve the root causes" (Westheimer \& Kahne, 2004, p. 240). Addressing social justice is central to critical pedagogy, the belief in man's unique ability to act, to be conscious participants in their own lives, and to have an influence on society as a whole (Giroux, 2011; Westheimer \& Kahne, 2004). Such an understanding of democracy, particularly related to the role of education in promoting democracy, can result, for example, in the use of inquiry-based teaching and dialogical methods that encourage pre-service teachers to engage with societal issues and mobilize when they recognize injustice and discrimination.

\section{Research methods}

The data analysed in this article constitutes a part of data collected in a Norwegian project on how democracy manifests itself in everyday life in education. In close collaboration with the Global Doing Democracy Research Project (GDDRP) a questionnaire has been translated into Norwegian from the English original. Two questionnaires were developed to cater for the two different response groups in this cycle of the project, one for teacher educators and one for pre-service teachers. The differences between the two questionnaires, however, are minimal. In this article, we make use of responses from teacher educators only. A pilot study was conducted in January 2015 within our own institution (teacher educators $n=52$ ) and the questionnaire was considerably shortened compared to the original one. In addition, a few questions were added based on national particularities.

The Norwegian Centre for Research Data (NSD) has approved the study. A random selection of 18 teacher education institutions in the country received the questionnaire in April/May 2015. Teacher education institutions usually offer a range of teacher education programs:

- Teacher education for Grade 1-7 (GLU1-7)

- Teacher education for Grade 5-10 (GLU5-10)

- Practical pedagogical education (PPU), a one year program for those who have already obtained a Bachelor, Master or Ph.D. degree with subjects relevant for teaching in school

- Master of Education (lektorutdanning), an integrated program in which they study subjects at Master level including theories of education and didactics

- Vocational teacher education (yrkesfaglærerutdanning), a program which provides theories of education and didactics for those who already have a formal education in their trade (e.g., carpenter, plumber). 
All teacher educators, approximately $\mathrm{N}=1000$, in the selected institutions received the questionnaire. We have not singled out a specific teacher education program as the entire Norwegian education system is expected to promote and develop democratic knowledge and competences (cf. Biseth, 2010). Out of the total invited to fill out the questionnaire, 153 responded $(n=153)$. Challenges with external validity are present in the study as we were prevented from a complete random sampling strategy and a low response rate (teacher educators $\mathrm{n}=153$ ). The results, nevertheless, are useful in gaining insight into some teacher educators' perspectives and self-reported practices of democracy. The low response rate in this study does not necessarily indicate a poor quality survey. A more important response quality indicator is if the characteristics of those who responded are significantly different from the characteristics of those who did not respond. We could experience, for example, a situation in which only teacher educators teaching social studies responded to the survey. This would most likely skew the results compared to a sample in which teacher educators teaching languages, religious studies, mathematics and science also responded to the survey. As teacher educators representing a variety of formal educational backgrounds and subjects they teach in the teacher education programs responded to the survey, it is not likely that these significant factors have resulted in a nonresponse error (Dillman et al., 2014).

Since this was an anonymous survey, we do not know which institution the respondents were employed at, but we know the teacher education program they teach in and the subject they teach in.

Table 1 - Respondents per teacher education program

\begin{tabular}{|c|c|c|c|c|c|}
\hline \multicolumn{7}{|c|}{ Teacher education program - respondents } \\
\hline GLU1-7 & GLU5-10 & PPU & $\begin{array}{c}\text { Master of } \\
\text { Education }\end{array}$ & $\begin{array}{c}\text { Vocation teacher } \\
\text { education }\end{array}$ & Other \\
\hline 73 & 78 & 36 & 25 & 6 & 56 \\
\hline
\end{tabular}

What is obvious in the sample is that it is quite common that teacher educators work in more than one teacher education program. For example, 58 of the respondents work in both GLU1-7 and GLU5-10. Eleven of the respondents work in both these programs in addition to PPU. The category "Other" includes other Master degree programs not directly related to the teaching profession, one-year courses not included in the regular teacher education programs, and in-service education programs funded by the Ministry of Education. Some respondents also teach at the Early Childhood Teacher Education program and ticked the box "Other". Our main goal was to reach teacher educators in the teacher education programs from primary through secondary education, and hence we did not have a box to tick for Early Childhood Teacher Education. 
Table 2 - Respondents per subject they teach

\begin{tabular}{|c|c|c|c|c|c|c|c|c|}
\hline \multicolumn{9}{|c|}{ Respondents per subject they teach } \\
\hline 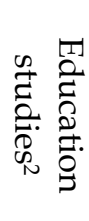 & 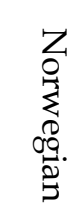 & 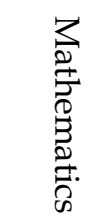 & 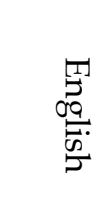 & 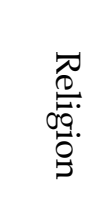 & $\begin{array}{l}\text { ñ } \\
\text { त्र } \\
\stackrel{0}{0} \\
0\end{array}$ & 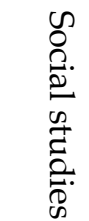 & 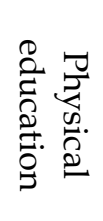 & 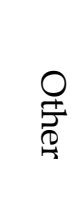 \\
\hline 49 & 17 & 12 & 10 & 13 & 15 & 25 & 9 & 31 \\
\hline
\end{tabular}

Since we ask questions related to the topic of democracy, we expected a large number of the respondents to be teachers of social studies. The largest group, however, are those who teach education studies. In teacher education, this last group of teacher educators constitute a large percentage of the staff. The group of "Other" refers to subjects such as Music, Food $\mathcal{E}$ Health, Arts $\mathcal{E}$ Crafts, research methods and other subjects at Master's level, and subjects in in-service programs. Taking a closer look at the distribution of staff across subjects in the group of respondents, it is close to the average distribution of staff according to subjects in a teacher education institution in Norway.

For this article we have analysed the following questions of the questionnaire:

a) How do you define democracy? (open-ended),

b) How do you understand the concept social justice? (open-ended),

c) How important do you consider social justice in a democracy? (closeended, Likert scale),

d) What can you do to promote democracy among your students? (openended), and

e) What can you do to promote social justice among your students? (open-ended).

The questions cover broad themes and could warrant several articles, but posed in a questionnaire, although open-ended questions, the responses are limited. In addition, we are interested in how the understanding of democracy trickles down into practice. As with the GDDRP, this current project intends to examine perceptions of democracy with an aim to developing a robust and critical democratic (teacher) education in the future. The analytical framework is based

\footnotetext{
${ }^{2}$ Education studies is a subject including both educational theories as well as the practical implications for teaching, classroom management, facilitation of learning, variation of learning strategies and more.
} 
on critical pedagogy and questions a), b) and c) will be analysed using the concepts of 'thick' and 'thin' democracy. References to social justice are not discussed on its own but seen as indicators of a commitment to 'thick' democracy. When analysing questions d) and e), we will use Westheimer and Kahne's (2004) three different notions of citizens to determine the correlation between the perceptions of democracy and what kind of citizen the teacher educator's promote through their self-reported classroom activities.

\section{Teacher educators' perceptions, experiences and understanding of democracy}

The majority of answers to the open-ended question "How do you define democracy" involve a description of democracy as government by the people, a variety of explanations mentioning free elections, and giving the people influence on the policies of the country. Several respondents add that a democratic system must ensure free speech, allowing critical voices to be raised without any risk for those involved, adherence to human rights and that a democracy must safeguard the rights of minorities. Some mention that democracy is more than a political system, rather giving an indication of values in a democratic society such as freedom of expression, respect, and the rule of law. Several respondents mention the duties of a citizen such as a duty to participate in society, to stay informed about current affairs and use their vote. Although several respondents mention participation, the participation predominantly seems connected to voting in election and as such can be described as more towards a thin understanding of democracy than the other end of the spectrum (Barber, 1984/2003). Despite references to the need to safeguard the minority and adhere to human rights, these answers are within a thin understanding of democracy, where representation, voting and the political system are in focus. A minority of answers, however, do mention the need for the system to defend the minority or at least limit the power of the "elite". One respondent (Respondent ID 44, social studies) 3 says, "The aim [of democracy] is social justice, transparency and having a choice between alternatives". Another openly mentioning that for him the main aim of a democracy is not giving voice to the people but rather to "make abuse of power and corruption difficult" (Respondent ID 125, mathematics). One respondent finishing his comment with the following, "An important question is the extent to which a society has real democracy or just a facade of democracy" (Respondent ID 75, education studies). Linking democracy and social justice, addressing power issues and questioning what a "real" democracy is, are all responses moving beyond a thin understanding of democracy, bringing in elements of thick democracy in their perceptions. Moreover, one of the respondents elaborates:

"I could write a lot about what democracy is, but in brief, it is primarily to act, to take action and as such is a form of political interaction between people, one that can never be taken for granted, one we will always have to work for and achieve anew. All interactions between people are political at one level. Democracy is

${ }^{3}$ All quotes translated from Norwegian to English by the authors. 
always under threat, and only through democratic interactions can democracy stay alive." (Respondent ID 77, arts and research methods).

The above respondent's reply stands out from other responses as it makes democracy more about people and relationships that exist in society compared with other responses focusing on systemic processes. This particular response corresponds with the idea of thick democracy discussed by Zyngier (2012, p. 5), where the social citizen is an individual, always in relationship with others and capable of reflexive agency.

The thin understanding of democracy as closely linked to formal political processes and institutions is present in the responses to question a). When responding to question c), "How important do you consider social justice in a democracy?", $95 \%$ of the respondents answered "important" or "very important" (i.e. \#4 and 5 on the Likert scale). We would expect this perceived solid connection between democracy and social justice should correlate with a sense of strong or thick democracy among the teacher educators. However, when analysing question b), "How do you understand the concept social justice?", we see a different picture. Many respondents refer to the role of the state in ensuring social justice, usually with regard to equal rights to health care and education. One respondent mentions the need for economic solidarity, globally and locally, but there are no examples of the teacher educators connecting the concept of social justice to themselves and their role as teacher educators or as an aim of education. The idea within thick democracy of agency, engagement and transformation on a societal level aiming toward a more just and sustainable society is conspicuous by its absence in our respondents answers.

With a majority of the teacher educators understanding democracy as an institutional characteristic of society, a way of governing through sharing of powers in an elected government, it is not surprising finding participation in formal elections as a prominent feature of the democratic experiences frequently mentioned. "Having a voice" is often stated as a core element of democracy, mainly through making your voice heard when participating in elections. Rights and responsibilities are also mentioned, but the respondents rarely elaborate on which specific rights and responsibilities democracy is about. Human rights, frequently present in the Education Act and National Curriculum in relation to democracy, are only to a limited extent a part of how democracy is defined by the teacher educators in this study.

What teacher educators do to promote democracy and social justice among preservice teachers will tell us more of whether teacher educators go beyond teaching about democracy and through critical thinking and debate, or stay within a thin democratic discourse.

\section{Teacher educators instilling democracy and social justice through their practices}

Through the questions "What can you do to promote democracy among your students?" and "What can you do to promote social justice among your students?" we wanted to elicit the practices, or potential practices, teacher 
educators undertake and perceive as appropriate. The phrasing of the questions is ambiguous. These can be understood as pointing to what the teacher educator is doing inside his or her classroom, for example, how they attend to their preservice teachers. The questions can also be interpreted as practices promoted outside the classroom, both through on-campus student life and development of skills for the future professional lives of the pre-service teachers. Regardless of this ambiguity, the responses to these questions provide insight into how teacher educators understand and practice their mandate in relation to democracy, indicating what knowledge, attitudes and skills they see as crucial in a good citizen.

When asked how they can work to promote democracy among students, participation in formal bodies such as the student parliament is prominent. This is concurrent with what is previously found in schools where democracy often is seen as taking part in the local student council (Biseth, 2011). The focus on participation in formal on-campus bodies correlates to the teacher educators' main understanding of democracy as a way of governing a society and voting as discussed in the previous section. Furthermore, the teacher educators emphasize the importance of promoting debates in the classroom. Participation in classroom discussions are by many respondents considered to be crucial in developing democratic competencies, and correlates with how teacher educators define "having a voice" as important. This could be interpreted as a way of preparing students for a deliberative democracy and indicate a perception of the participatory citizen as the ideal citizen (Westheimer \& Kahne, 2004).

Other ways of promoting student participation and providing them a voice are how the teacher educators facilitate students' influence, as one respondent puts it: "In my teaching I let the students influence within the framework we have and where it is acceptable" (Respondent ID 120, education studies). It seems as if this teacher educator provides the students with the possibility of influencing the teaching. However, it is limited by what is termed "the framework", which could refer to systemic issues or factors the teacher educator himself finds appropriate. In addition, the influence should only take place where it is "acceptable". The respondent does not appear to see a contradiction between the expected participation of the students yet the boundaries he has the power to define. Although there could be limitations set by the education system, the respondent does not challenge these. The education system prescribes that preservice teachers be able to influence teacher education through meetings with the individual teacher as well as the team of teacher educators to discuss content of courses, assessment methods and scheduling of course work, and to evaluate each course. A significant number of the responding teacher educators include their pre-service teachers in discussions that have practical implications for teaching activities and, hence, provide the students with possibilities to influence their own everyday lives. If pre-service teachers engage in this and teacher educators find this the most effective mode of promoting democracy, then it is possible to describe this as education promoting personally responsible citizens. 
When responding to the question on how they can promote social justice, the teacher educators seem far less confident than on the previous question. This is despite the fact that $95 \%$ of the respondents understand social justice to be an important or very important part of democracy as discussed above. Few seem to see this as their job. They tend to see this as outside the scope of their mandate or their powers. The most prominent feature mentioned, however, is inclusion, i.e. how they can adjust teacher education to include all students, ensuring an inclusive community of learners in which all can succeed regardless of socioeconomic background, gender and race - as illustrated by this respondent:

"Ensuring a variation of teaching methods to facilitate all students and to adjust to different academic levels. The most important thing, however, is to work with the social class environment and culture. If we can contribute to students defending equality, justice and inclusion it becomes easier to achieve social justice." (Respondent ID 95, education studies).

A targeted approach to education to facilitate all pre-service teachers' capabilities is seen as social justice by this teacher educator. In addition, promoting social justice lies deeply embedded in an inclusive classroom environment. The focus is on the culture promoted within the classroom of the pre-service teachers, seeing social justice as providing the students with more equal opportunities for succeeding in their education. Achieving this appears as core in developing future teachers' capabilities in promoting social justice, without the teacher educator providing the link between what goes on in the classroom and how this will develop the pre-service teachers' capabilities to act upon issues of social injustice in their own classrooms and in society at large.

One of the respondents gives voice to activities moving beyond individually adjusted education:

"I cannot influence the social situation of my students, but my teaching and their practical experiences may increase their support in working towards an increase of social justice. Knowledge of social diversity in Norway and the world is a foundation, but attaining experiences through excursions, study tours, fundraising etc. is necessary to transform the knowledge into lasting attitudes and actions." (Respondent ID 55, social studies).

This respondent acknowledges the potential variation of the pre-service teachers' backgrounds and lives. The respondent addresses issues of social justice by providing students with not only a good role model but also practical experiences designed to instil in them a sound understanding. He points to the importance of transforming knowledge into attitudes and actions, something of a necessity if the aim is to foster future teachers capable of addressing the democratic mandate assigned to the education sector. As such, this respondent clearly promotes a more participatory citizenship as issues of social injustice and potential actions to address this are on the table. Among the respondents in general, however, discussions in the classroom about social injustice in society seem to be the predominant way of speaking to social justice. Although the 
discussion is about topics of social justice outside their immediate classroom, none of the respondents indicates an interest in going into root causes of injustice in society, and then supporting their pre-service teachers in how to work to address these.

Some respondents include the capability for critical thinking in their work towards social justice. One respondent was also concerned with democracy as critical thinking, interaction and community rather than representation and political systems:

"I always work with co-creative, investigative processes and with a critical view on the current education system, teaching, learning, education and education policy. I work with myself, knowing that I must be willing to change, to learn and learn from all the pupils and students I meet. I try to make these encounters "real", which means that I, as an educator find myself surrounded by "risk". I must however be open to what the students and pupils bring with them." (Respondent ID 77, arts and research methods).

Although the respondent understand critical thinking as essential to democracy, he makes no mention of any concrete issues or actions he would engage the students in other than critical thinking and dialogue. Such a personal and interactional view of democracy could therefore result in a teacher education closer to the ideals of the personally responsible citizen than the ideals of the justice-oriented citizen.

Despite a clear awareness of differences in power and influence within society, it does not seem to lead the teacher educators to encourage students to exercise their voice in society at large or engage in a way that will lead to a transformation of power and influence. In other words, there seems to be little evidence of teacher educators instilling an understanding of thick democracy among their students.

\section{Discussion of results}

The aim of the study has been to gain insight into teacher educators' attentiveness to democracy, i.e. how they understand democracy and how they describe their own role in and practices of instilling democratic competencies and values in pre-service teachers. The results of this study seem to indicate that teacher educators primarily understand democracy related to a societal structure, a way of politically organizing a society in which elections are a core activity. Hence, they endorse a thin understanding of democracy. This corresponds with how they perceive their own practice in that the two dominant ways of promoting democracy are to encourage students to take part in formal participatory structures and engaging students in discussions and debates within the classroom.

Even though there seems to be a correspondence with an understanding of democracy and the teaching practices, some variations still exist as illustrated in Figure 3 below. Although many (hence the thick arrow) respondents provided 
answers indicating that their perceptions and understanding of democracy could be placed towards thin democracy on the left end of the continuum, none are placed at the very end of this side. We also had quite a significant group of respondents who provided descriptions of democracy indicating that they have a more in-depth understanding of democracy, moving away from a thin perception.

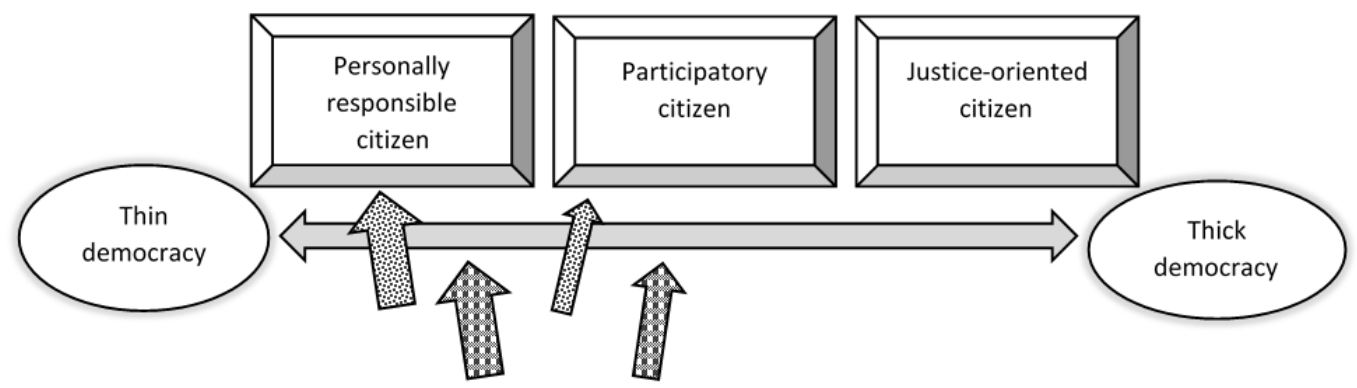

[․ㅛㅛㅛ Teacher educators' perceptions and understanding of democracy

Teacher educators' teaching practices

Figure 3 - How teacher educators understand and practice democracy

We have argued that the ways in which teacher educators understand democracy will influence how they teach about democracy and what kind of citizenry they promote (Westheimer, 2015; Westheimer \& Kahne, 2004). In this study, it seems to be a valid argument - for the most part. The majority of the teacher educators focus on teaching practices promoting personally responsible citizens, i.e. indicating a thin understanding of democracy, even more so than how the teacher educators themselves claim to perceive democracy. The same trend is visible for respondents with a more nuanced perception of democracy; only a limited number of those respondents report on practices that can be categorized as educating to promote participatory citizens. Why this is so is not possible for us to judge based on responses in a questionnaire. What is also interesting is how $95 \%$ of the teacher educators assess social justice as a core element of democracy, yet not as a part of their practices when educating preservice teachers. It could for example be possible to address how democratic citizenship can play a role in developing a society focusing on sustainable development, two crosscutting themes in the National Curriculum.

The raising of awareness in pre-service teachers that a sustainable and prosperous democracy is about participation that leads to change and transformation, responding to current dilemmas of modern politics, seems therefore not to be an essential trait of the perceptions and practices identified by teacher educators of this study. It could be argued, however, that this moves beyond what can be expected of teacher education and teacher educators. We acknowledge that the ways in which teacher educators have responded in this study indicate practices that contribute to developing future teachers who are able to stimulate an understanding of democracy, democratic participation and the ability for critical reflection. Yet, teacher education is also aimed at preparing future teachers who can respond to the mandate given to the education sector in 
which a thicker understanding of democracy is required. In effect, to foster future citizens capable of further stimulating a society built on democratic principles, such as respect for human dignity, equality, solidarity, justice and human rights, as set forth in the Education Act (Ministry of Education, 1998), requires teacher to hold a thick understanding of democracy, capable of doing democracy within and outside of their classrooms as justice-oriented citizens. We therefore see a clear need to address how these issues are to become more prominent in the Norwegian teacher education.

\section{Directions for future research}

This study is limited to a Norwegian context and as such, our directions for future research are twofold, one at a national level, one at a general level.

Although Norwegian teenagers perform relatively well in the International Civic and Citizenship Education Study (ICCS2016) (Huang et al., 2017), we call for an investigation of the role of the education sector in these performances. Previous studies in schools (cf. Biseth, 2011), among pre-service teachers (Wistrøm \& Madsen, 2018; Eriksen, 2018), and in this current study indicate a thin understanding of democracy among teachers and teacher educators. These results point in a direction of more targeted quasi-experimental studies to obtain information on what kind of citizenship education is effective in promoting a thick understanding of democracy with social justice oriented citizenship education among pre-service teachers. Action research could also be an avenue to follow to investigate how to strengthen citizenship education for a sustainable democracy in the future. Especially is this important when democracy, democratic and human rights values seem to be under threat with political extremist views and practices.

A general direction for future research, both nationally and internationally, is to engage increasingly with critical research on the topic of sustainable democracy within teacher education. Schools are often the target population of educational researchers. Educators have commonly graduated from some sort of teacher education. We assert that critical research in and on teacher education, as well as together with teacher educators have an important role to play in promoting an improved democratic education system for the $21^{\text {st }}$ century.

\section{References}

Barber B. R. (1984/2003) Strong Democracy: Participatory Politics for a New Age. Berkeley, California: University of California Press.

Biseth, H. (2009). Democracy and education in a multicultural Scandinavia: what mandate is designated to educators? Intercultural Education, 20(3), 243-254, https://doi.org/10.1080/14675980903138590

Biseth, H. (2010). Diversity and democracy in Scandinavian schools: Examples of good practices? In C. Govaris \& S. Kaldi (Eds.), The educational challenge of diversity in the international context (pp. 75-98). Münster: Waxmann.

Biseth, H. (2011). Citizenship Education in Scandinavian Multicultural Schools: A Comparative Study of Students' and Teachers' Perceptions. Citizenship Teaching and Learning, 7(1), 71-88, https://doi.org/10.1386/ctl.7.1.71_1 
Biseth, H. (2012). Educators as custodians of democracy: A comparative investigation of democracy in multicultural school environments in the Scandinavian capitals. (Ph.D.), University of Oslo, Oslo.

Carr, P. R., Zyngier, D. \& Pruyn, M. (2014). Can Educators Make a Difference? Experimenting with, and Experiencing, Democracy in Education. Greenwich: IAP Information Age Publishing, Inc.

Dillman, D. A., Smyth, J. D. \& Christian, L.M. (2014). Internet, Phone, Mail, and MixedMode Surveys: The Tailored Design Method. Hoboken: Wiley.

Eriksen, K. G. (2018). Bringing Democratic Theory into Didactical Practice. Concepts of Education for Democracy Among Norwegian Pre-service Teachers. Interchange, pp. 1-17, https:/ / doi.org/10.1007/s10780-018-9332-7

Fjeldstad, D., Lauglo, J. \& Mikkelsen, R. (2010). Demokratisk beredskap: Kortrapport om norske ungdomsskoleelevers prestasjoner og svar på spørsmål $i$ den internasjonale demokratiundersøkelsen [Democratic engagement: Short report on Norwegian lower secondary students' performance og responses to questions in the international study on democracy] - International Civic and Citizenship Education Study (ICCS 2009). Oslo: Universitetet i Oslo/International Association for the Evaluation of Educational Achievement (IEA).

Gandin, L. A. \& Apple, M. W. (2002). Thin versus thick democracy in education: Porto Alegre and the creation of alternatives to neo-liberalism. International Studies in Sociology of Education, 12, 99-116, https://doi.org/10.1080/09620210200200085

Giroux, H. A. (2011). On Critical Pedagogy. NYC/London: Continuum International.

Haugen, C. R., Hestbek, T. A. \& Øfsti, R. (2014). Pedagogikk, politikk og etikk: demokratiske utfordringer og muligheter i norsk skole [Pedagogy, politics and ethics: democratic challenges and possibilities in the Norwegian school system]. Oslo: Universitetsforlaget.

Huang, L., Ødegård, G., Hegna, K., Svagård, V., Helland, T. \& Seland, I. (2017). Unge medborgere. Demokratiforståelse, kunnskap og engasjement blant 9.-klassinger i Norge [Young citizens: Understanding of democracy, knowledge and engagement among Grade 9 students in Norway]: The International Civic and Citizenship Education Study (ICCS) 2016. Oslo: NOVA-Høgskolen i Oslo og Akershus (HIOA)/ International Association for the Evaluation of Educational Achievement (IEA).

Kunnskapsdepartementet [Ministry of Education and Research]. (2016). Fag - Fordypning - Forståelse: En fornyelse av Kunnskapsløftet (Meld. St. 28 2015-2016) [Subject Specialisation - Understanding: A renewal of the Knowledge Promotion Curriculum (White Paper 28: 2015-2016)]. Oslo: Kunnskapsdepartementet.

Levinson, B. A. U. (2011). Toward an Anthropology of (Democratic) Citizenship Education. In B. A. U. Levinson \& M. Pollock (Eds.), A Companion to the Anthropology of Education (pp. 279-298). Oxford: Wiley-Blackwell, https://doi.org/10.1002/9781444396713

Mikkelsen, R., Fjeldstad, D. \& Lauglo, J. (2011). Morgendagens samfunnsborgere. Norske ungdomsskoleelevers prestasjoner og svar på spørsmål $i$ den internasjonale demokratiundersøkelsen ICCS [Citizens of tomorrow: Norwegian lower secondary students' performance og responses to questions in the international study on democracy ICCS]. Oslo: Acta Didactica.

Ministry of Education (1998). The Education Act. Oslo: Ministry of Education.

Ministry of Education and Research (2016a). Regulations Relating to the Framework Plan for Primary and Lower Secondary Teacher Education for Years 1-7. Oslo: Ministry of Education and Research.

Ministry of Education and Research (2016b). Regulations Relating to the Framework Plan for Primary and Lower Secondary Teacher Education for Years 5-10. Oslo: Ministry of Education and Research.

Parker, W. (1996). "Advanced" Ideas about Democracy: Toward a Pluralist Conception of Citizenship Education. Teachers College Record, 98(1), 104-125. 
Schulz, W., Ainley, J., Fraillon, J., Kerr, D. \& Losito, B. (2010). Initial Findings from the IEA International Civic and Citizenship Education Study. Amsterdam: International Association for the Evaluation of Educational Achievement (IEA).

Selle, P. \& Østerud, Ø. (2006). The eroding of representative democracy in Norway. Journal of European Public Policy, 13(4), 551-568, https:// doi.org/10.1080/13501760600693929

Solhaug T. (2003). Utdanning til demokratisk medborgerskap [Education for democratic citizenship]. Oslo: Institutt for lærerutdanning og skoleutvikling, Universitetet i Oslo.

Statistics Norway (2018). Key figures for the population. Retrieved July 8, 2018 from https://www.ssb.no/en/befolkning/nokkeltall/population

Stray, J. H. \& Sætra, E. (2015). Samfunnsfagets demokratioppdrag i fremtidens skole: En undersøkelse av samfunnsfaglæreres opplevelse av fagets rammebetingelser og Ludvigsen-utvalgets utredninger [The democratic assignment of social studies in the school of the future]. Norsk pedagogisk tidsskrift, 99, 460-471.

The Economist Intelligence Unit (2018). Democracy Index. Retrieved July 8, 2018 from https://infographics.economist.com/2018/DemocracyIndex/

Westheimer, J. (2015). What Kind of Citizen? Educating Our Children for the Common Good. New York: Teachers College Press.

Westheimer J \& Kahne J. (2004). What kind of citizen? The politics of educating for democracy. American Education Research Journal, 41(2), 237-269, https://doi.org/10.3102/00028312041002237.

Wistrøm, Ø. \& Madsen, M. (2018). Democracy and science: two sides of the same coin?. Nordisk tidsskrift for pedagogikk og kritikk, 4, 50-68, http://dx.doi.org/10.23865/ntpk.v4.559

Zyngier D. (2012). Rethinking the Thinking on Democracy in Education: What Are Educators Thinking (and Doing) About Democracy? Education Sciences, 2(1), 121, https://doi.org/10.3390/educ2010001. 